Brit. J. soc. Med. (1951), 5, 13-33

\title{
SPREAD OF TUBERCULOSIS FROM HOUSE TO HOUSE
}

\author{
BY \\ JOSEFINE WEBB* and ALICE STEWART \\ WITH A STATISTICAL APPENDIX BY \\ IAN SUTHERLAND \\ Institute of Social Medicine, Oxford
}

This investigation originates from an observation made in 1948 that many tuberculous patients in Northampton lived next door to one another. It was decided to find out whether the pattern of the disease in this town suggested that persons living next door to tuberculous subjects are unduly prone to contract the disease.

The first step was to discover the position of houses from which cases of tuberculosis had been notified from 1921 to 1948 . We next studied other possible influences on the pattern of the disease, to see whether, allowing for these, the position of the affected houses suggested a random distribution of cases, or revealed the transmission of disease between neighbours. Finally, to decide whether the setting of the investigation was exceptional, the population and social conditions of Northampton were examined, by comparing the borough as a whole with other towns, and by comparing different districts within the borough.

\section{Medical Survey}

Tuberculosis Notifications. Northampton County Borough, 1921-1948.Between January 1, 1921, and December 31, 1948, notifications of tuberculous disease of the lungs, meninges, and other sites were received from 2,871 houses, or approximately one in every ten houses in the borough (see Table I). Of every ten cases notified, eight were pulmonary and two non-pulmonary (total 3,346). $\dagger$

(a) Age and Sex.-Throughout the period of study the tuberculosis death rate for Northampton County Borough has followed the same trend as the rate for England and Wales as a whole, and fatal cases have shown a similar age and sex distribution. Between 1938 and 1948-the only period for which notification

* In receipt of a grant from the Medical Research Council.

+ Tuberculosis notifications from houses demolished before or built after 1936, and cases included in the official register of tuberculosis notifications but subsequently removed as "diagnosis not established ", are not included in the present investigation. All post-mortem diagnoses are included. Throughout the period of study Dr. Laughton, Chest Physician to Northampton County Borough, has been in sole charge of the tuberculosis records. 
TABLE I

Tuberculosis Notifications. NORTHAMPTON 1921-1948

COMPaRISON BeTWEen CASE INCIDENCE AND HOUSE INCIDENCE

\begin{tabular}{|c|c|c|c|}
\hline Group & Disease Category & No. of Cases & $\begin{array}{c}\text { Annual Rate } \\
\text { per } 10,000\end{array}$ \\
\hline \multirow[t]{2}{*}{ Notified Persons } & $\begin{array}{l}\text { Pulmonary } \\
\text { Miliary and meningeal } \\
\text { Other sites }\end{array}$ & $\begin{array}{r}2,674 \\
164 \\
508\end{array}$ & $\begin{array}{l}9 \cdot 8 \\
0 \cdot 6 \\
1.9\end{array}$ \\
\hline & Total & 3,346 & $12 \cdot 4$ \\
\hline \multirow[t]{2}{*}{ Affected Houses } & $\begin{array}{l}\text { Pulmonary } \\
\text { Miliary and meningeal } \\
\text { Other sites }\end{array}$ & $\begin{array}{r}2,340 \\
160 \\
496\end{array}$ & $\begin{array}{r}31 \cdot 2 \\
2 \cdot 1 \\
6 \cdot 6\end{array}$ \\
\hline & Total & $2,871^{*}$ & $38 \cdot 3$ \\
\hline
\end{tabular}

* In 119 houses there were cases of tuberculosis belonging to two different categories (e.g. pulmonary and meningeal or pulmonary and other sites) and in three houses there were cases belonging to all three categories. Hence this figure is 125 less than the sum of the figures in the same column.

TABLE II

Tuberculosis Notifications (Persons over the Age of 14 years). Northampton 1921-1939 OCCUPATIONAL ANALYSIS

\begin{tabular}{|c|c|c|c|c|}
\hline \multirow[b]{2}{*}{ Occupational Group } & \multicolumn{2}{|c|}{ Males } & \multicolumn{2}{|c|}{ Females } \\
\hline & $\begin{array}{c}\text { No. } \\
\text { employed* }\end{array}$ & $\begin{array}{c}\text { Tuberculosis } \\
\text { notifications } \\
\text { rate per } \\
10,000 \\
\text { per annum }\end{array}$ & $\begin{array}{l}\text { No. } \\
\text { employed* }\end{array}$ & $\begin{array}{c}\text { Tuberculosis } \\
\text { notifications } \\
\text { rate per } \\
10,000 \\
\text { per annum }\end{array}$ \\
\hline 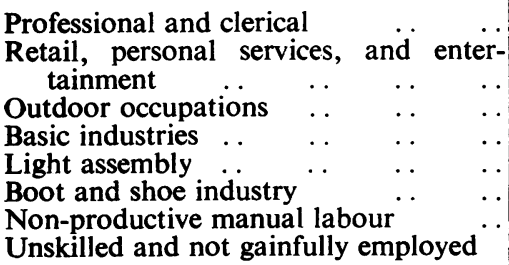 & $\begin{array}{l}4,064 \\
5,083 \\
4,645 \\
1,212 \\
3,956 \\
8,871 \\
1,202 \\
5,473\end{array}$ & $\begin{array}{r}11 \cdot 1 \\
12 \cdot 3 \\
10 \cdot 3 \\
14 \cdot 8 \\
14 \cdot 9 \\
23 \cdot 8 \\
19 \cdot 7 \\
9 \cdot 7\end{array}$ & $\begin{array}{r}2,755 \\
4,642 \\
107 \\
-7,285 \\
5,480 \\
7 \\
24,308\end{array}$ & $\begin{array}{l}13 \cdot 7 \\
9 \cdot 7 \\
\overline{-} \\
19 \cdot 6 \\
\frac{20 \cdot 3}{6 \cdot 5}\end{array}$ \\
\hline Total & 34,506 & $15 \cdot 3$ & 39,584 & $12 \cdot 3$ \\
\hline
\end{tabular}

* 1931 Census (persons over the age of 14 years).

records for England and Wales are available - there appears to have been a slight excess of notifications in Northampton. This difference, which is confined to persons between the ages of 15 and 25 years, and to the years 1940 to 1946, is probably due to the fact that the records for England and Wales apply to the civilian population only, whereas those for Northampton include men and women who were serving in the armed forces.

(b) Occupation.-An occupational analysis of cases over the age of 14 years notified in Northampton between 1921 and 1939 is shown in Table II. This Table, 
which does not include cases notified after the outbreak of war, is based on information in the 1931 Census, and shows that the incidence of tuberculosis is higher in the boot and shoe industry than in any of the other large occupational groups-a finding consistent with the Registrar-General's statistics of occupational mortality. (Registrar-General's Decennial Supplement for England and Wales, 1931.)

TABLE III

TUberculosis Notifications. NORTHAMPton 1921-1948

Comparison of Case Incidence in Good, Fair, and Poor Houses of Central and Peripheral

Affected houses expressed as a percentage of all houses

\begin{tabular}{|c|c|c|c|c|}
\hline Disease Category & $\begin{array}{c}\text { Grading of } \\
\text { House* }\end{array}$ & $\begin{array}{c}\text { Peripheral } \\
\text { Wards** }\end{array}$ & Central Wards* & All Regions \\
\hline \multirow[t]{2}{*}{ Pulmonary } & $\begin{array}{l}\text { Good } \\
\text { Fair } \\
\text { Poor }\end{array}$ & $\begin{array}{r}5 \cdot 75 \\
9 \cdot 42 \\
10 \cdot 76\end{array}$ & $\begin{array}{r}6 \cdot 46 \\
9 \cdot 80 \\
12 \cdot 35\end{array}$ & $\begin{array}{r}5.96 \\
9 \cdot 62 \\
11 \cdot 90\end{array}$ \\
\hline & Total & $7 \cdot 98$ & $9 \cdot 62$ & $8 \cdot 74$ \\
\hline \multirow[t]{2}{*}{ Other Sites } & $\begin{array}{l}\text { Good } \\
\text { Fair } \\
\text { Poor }\end{array}$ & $\begin{array}{l}1 \cdot 76 \\
2 \cdot 63 \\
4 \cdot 82\end{array}$ & $\begin{array}{l}1 \cdot 42 \\
2 \cdot 48 \\
3 \cdot 58\end{array}$ & $\begin{array}{l}1.69 \\
2.57 \\
3.95\end{array}$ \\
\hline & Total & $2 \cdot 39$ & $2 \cdot 45$ & $2 \cdot 42$ \\
\hline Total All Cases & .. & $9 \cdot 94$ & $11 \cdot 68$ & $10 \cdot 72$ \\
\hline
\end{tabular}

* See p. 23 for definitions of good, fair, and poor houses, and of central and peripheral wards.

(c) Houses.-The electoral wards and houses in Northampton in which cases of tuberculosis occurred are shown in Tables III and X, the wards being grouped in two classes (central and peripheral) and the houses in three (good, fair, and poor).*

The case incidence shows the usual social gradient, being highest in the poor and lowest in the good houses, and slightly higher in the central than in the peripheral zone. Only 82 of the 640 streets in the town of Northampton remained free from tuberculosis during the period of study. These streets were fairly evenly distributed throughout the town and showed no tendency to concentrate in the better-class districts.

In deciding whether the position of houses from which tuberculosis notifications had been received gave evidence of spread of infection between neighbours, two points had to be considered: the spatial arrangement of the affected houses, and the time relationships of the cases.

* See Section 2 (Sociological Survey) for a definition of good, fair, and poor houses and for a general description of the electoral wards included in the peripheral and central zones of Northampton. The houses were classified by Dr. Laughton and the tuberculosis health visitor, Miss C. Reese, S.R.N. (both of whom have worked in the Tuberculosis Dispensary for Northampton County Borough for over 20 years). 


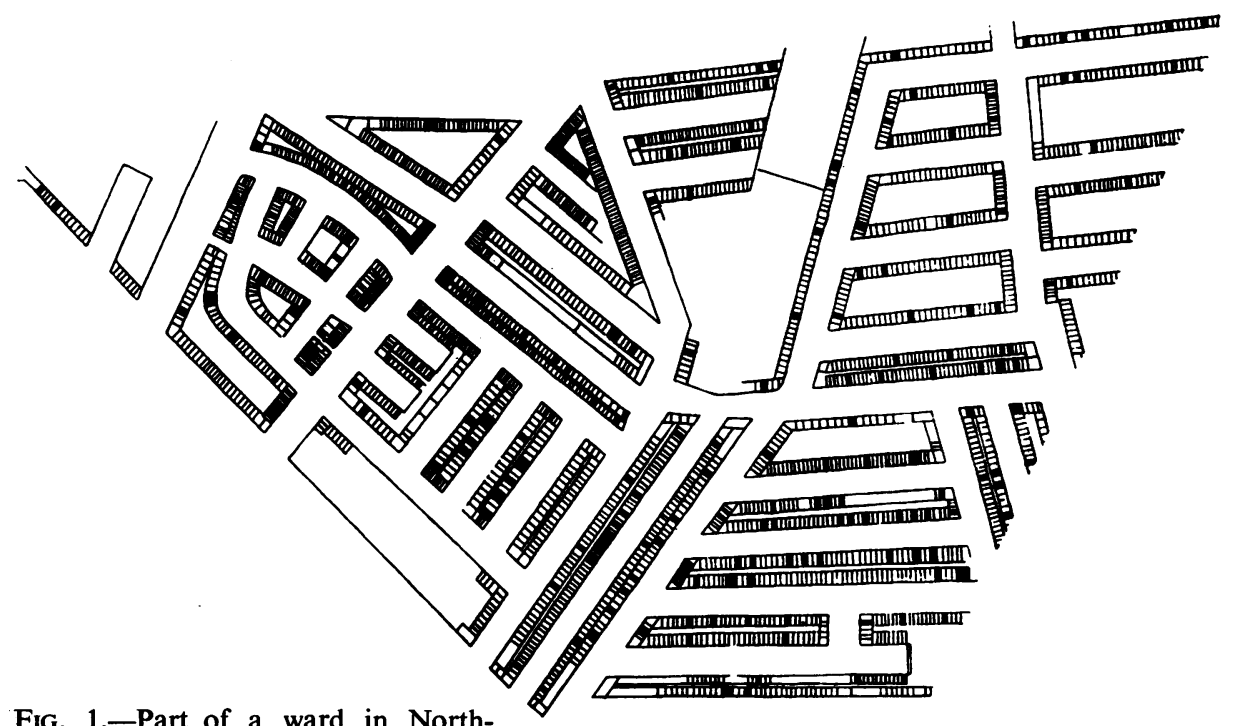

Fig. 1.-Part of a ward in Northampton showing the distribution of houses from which cases of tuberculosis were notified, 1921-48
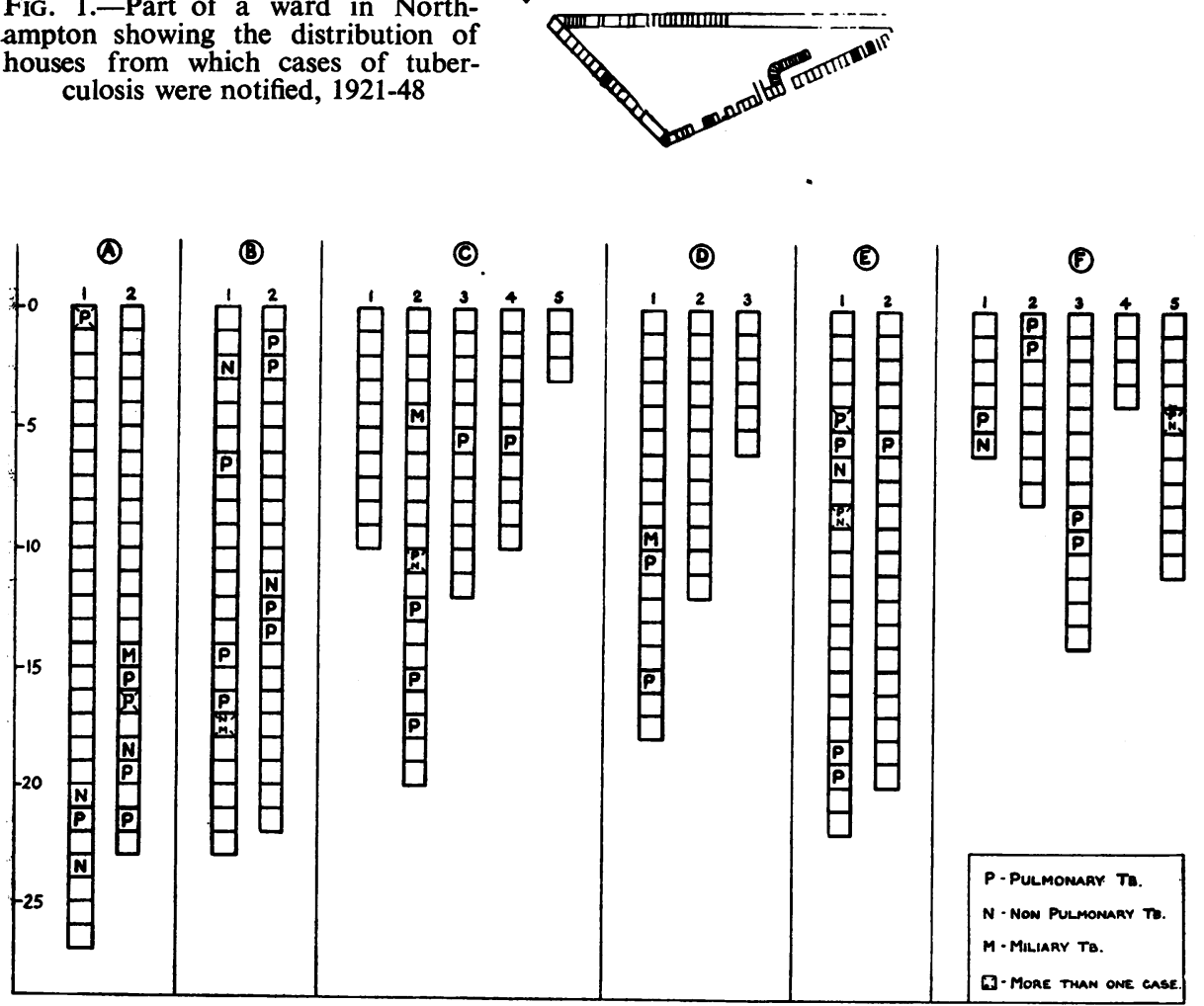

Fig. 2.-Position of affected houses in nineteen rows of houses in six streets, Northampton 1921-1948. 
Spatial Arrangement of Affected Houses.-The affected houses in one of the central wards in Northampton are shown in Fig. 1. They are widely scattered, but it is far from certain that they do not tend to be more closely grouped together than if they were randomly distributed. To decide, therefore, whether the number of next-door pairs exceeds expectation, more must be known about the laws governing their chance distribution than can be gleaned from a straightforward inspection of a map. The mathematical theory of the random distribution of points in one dimension has already been intensively studied; and by extending the results of this work and applying new formulae (see Statistical Appendix) to the present data, more may be said about the linear arrangements of the affected houses than would otherwise have been possible.

To make the necessary calculations the following facts had to be assembled:

(i) the total number of uninterrupted rows of dwelling-houses in the town;

(ii) the number of houses in each of these rows or " sections";

(iii) the disposition of the affected houses in each section. The recording system is shown diagrammatically in Fig. 2.

In both the central and peripheral zones of the town a few long streets contained more than one type of house, but in neither region did the division of houses into good, fair, and poor classes involve the division of any continuous row of domestic buildings.

It was then possible to count the number of occasions in which notifications had been received from next-door pairs of houses (Table IV). Other " pairs" of affected houses (separated by $1,2,3,4$, or 5 unaffected houses) were also included in the calculations. Since subsequent analysis of the " separated pairs " revealed little of medical interest, no further mention of these houses will be made in this part of the paper, but detailed findings are given in the Tables and in the Statistical Appendix.

The results of the calculations based on these facts are shown in Table V (overleaf) and Table XII (p. 29). In the former the observed incidence of next-door pairs of affected houses is expressed as a percentage of the expected incidence (see Statistical Appendix).

TABLE IV

TuberCulosis NOTIFICATIONS. NORTHAMPTON 1921-1948

Spatial Relationships of Cases in Next-DOOR Houses, etc.

I. Numerical incidence of next-door pairs of affected houses, etc.

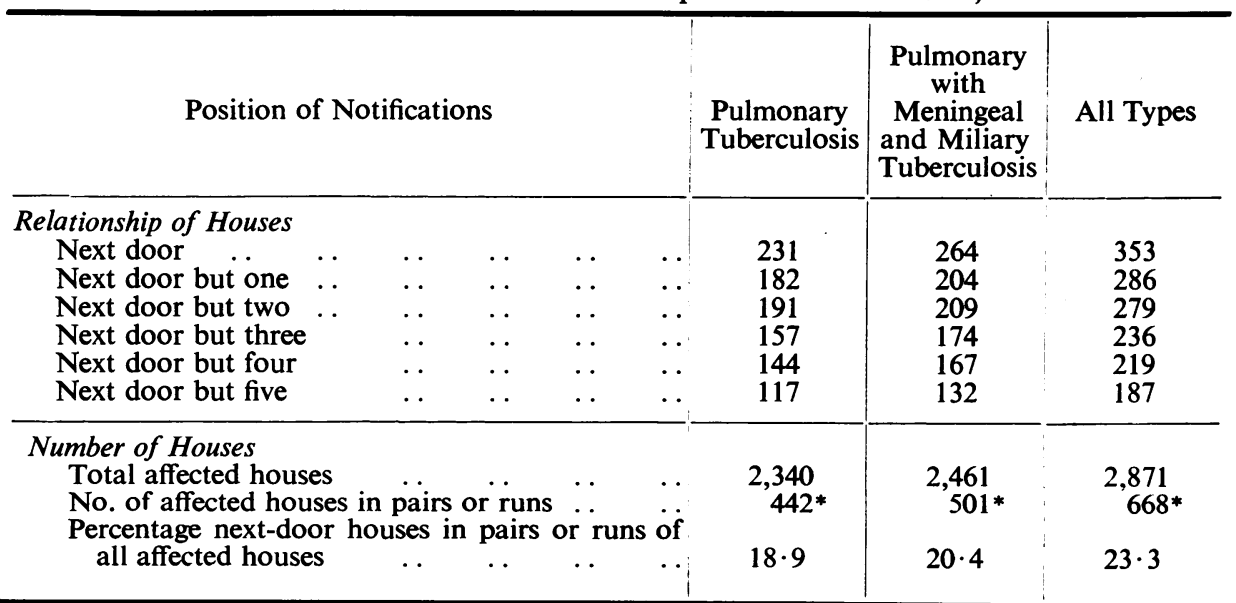

* This figure is less than twice the number of next-door houses because in some instances a series of three or more adjacent houses were affected. In these longer series the number of houses involved is only one more than the number of pairs. 
According to Table $\mathrm{V}$, the number of next-door pairs is greater than the number which would have occurred by chance.* The difference between the observed and expected numbers in the linear series is only slightly affected by the type of case containea in the houses. Thus, if all types of tuberculosis are grouped together, the next-door pairs exceed expectation by 19 per cent.; if pulmonary tuberculosis is taken alone, the excess is 16 per cent.; and if pulmonary, miliary, and meningeal cases are grouped together and other non-pulmonary cases omitted, it is 20 per cent.

TABLE $V$

TUBERCULOSIS NOTIFICATIONS. NORTHAMPTON 1921-1948

Spatial Relationships of Cases in Next-door Houses, etc.

II. Comparison of observed and expected relationships. Next-door pairs, etc., of affected houses expressed as a ratio of the expected number of next-door pairs, etc.

(N.B.- In each cell the expected number $=100$ )

\begin{tabular}{l|c|c|c}
\hline Position of Notifications & $\begin{array}{c}\text { Pulmonary } \\
\text { Tuberculosis }\end{array}$ & $\begin{array}{c}\text { Pulmonary } \\
\text { with Meningeal and } \\
\text { Miliary Tuberculosis }\end{array}$ & All Types \\
\hline Next door & 116 & 120 & 119 \\
\hline Next door but one or two & 106 & 106 & 106 \\
\hline Next door but three or four & 100 & 103 & 100 \\
\hline Next door but five & 89 & 91 & 89 \\
\hline
\end{tabular}

Time Relationships of Cases in Nearby Houses.-The notification dates were then examined to see whether the cases situated in the same or nearby houses were more closely related in time than would be expected from chance alone. The intervals between the years of notification of pairs of cases occurring in the same or nearby houses were enumerated, and the data analysed in three groups:

(i) all types of tuberculosis;

(ii) pulmonary, miliary, and meningeal;

(iii) pulmonary tuberculosis alone.

The time intervals between pairs of cases occurring in the same house, next-door houses, and houses next-door-but-one, etc., were enumerated separately (Tables VI, VII, opposite, and XIII, p. 32).

Table VI shows that, within a period of 12 years, second notifications from the same house were far more frequent that second notifications from next-door houses. Table VII shows that even from next-door houses second notifications exceed the number expected, the findings being only slightly affected by the type of case contained in the house. Thus, for all forms of tuberculosis the number of second cases in next-door houses exceeds expectation by 27 per cent.; for pulmonary tuberculosis the excess is 33 per cent.; and for pulmonary, meningeal, and miliary it is 35 per cent.

Comparison of Cases in NeXt-door Houses with Cases occurring ElseWHERE.-Thus far the findings suggest that there has been a tendency for tuberculosis to occur more often and in a shorter space of time in next-door houses than would have been the case had it been randomly distributed. On the face of it this

* This calculation ignores the relative position of affected houses on opposite sides of a street, and only concerns the houses from which cases were first notified. Subsequent addresses could not be taken into account since dates of removal and periods of residence at the new addresses were not known. 


\section{SPREAD OF TUBERCULOSIS FROM HOUSE TO HOUSE \\ TABLE VI}

TUberculosis Notifications. NORTHAMPTON 1921-1948

Time Relationships of Cases in Next-DoOR Houses, etc.

I. Numerical incidence of second notifications occurring before and after 12 years

\begin{tabular}{|c|c|c|c|c|c|c|c|c|c|}
\hline \multirow{3}{*}{ Position of Cases } & \multirow{2}{*}{\multicolumn{3}{|c|}{ Pulmonary Tuberculosis }} & \multirow{2}{*}{\multicolumn{3}{|c|}{$\begin{array}{c}\begin{array}{c}\text { Pulmonary with } \\
\text { Meningeal and Miliary } \\
\text { Tuberculosis }\end{array} \\
\text { Time Interval }\end{array}$}} & \multicolumn{3}{|c|}{ All Types } \\
\hline & & & & & & & \multicolumn{3}{|c|}{ Time Interval } \\
\hline & $\begin{array}{c}0-12 \\
\text { years }\end{array}$ & $\begin{array}{c}\text { Over } 12 \\
\text { years }\end{array}$ & Total & $\begin{array}{l}0-12 \\
\text { years }\end{array}$ & $\begin{array}{c}\text { Over } 12 \\
\text { years }\end{array}$ & Total & $\begin{array}{l}0-12 \\
\text { years }\end{array}$ & $\begin{array}{c}\text { Over } 12 \\
\text { years }\end{array}$ & Total \\
\hline $\begin{array}{l}\text { Same house } \\
\text { Next door } \\
\text { Next door but one } \\
\text { Next door but two }\end{array}$ & $\begin{array}{l}318 \\
214 \\
164 \\
141\end{array}$ & $\begin{array}{l}65 \\
90 \\
71 \\
85\end{array}$ & $\begin{array}{l}383 \\
304 \\
235 \\
226\end{array}$ & $\begin{array}{l}361 \\
245 \\
182 \\
153\end{array}$ & $\begin{array}{r}75 \\
104 \\
85 \\
97\end{array}$ & $\begin{array}{l}436 \\
349 \\
267 \\
250\end{array}$ & $\begin{array}{l}442 \\
324 \\
255 \\
215\end{array}$ & $\begin{array}{r}99 \\
150 \\
130 \\
127\end{array}$ & $\begin{array}{l}541 \\
474 \\
385 \\
342\end{array}$ \\
\hline
\end{tabular}

TABLE VII

Tuberculosis Notifications. NORThampton 1921-1948

Time Relationships of Cases in NeXt-DOOR Houses, etc.

II. Second notifications occurring within 12 years expressed as a ratio of the expected number. (N.B.- - In each cell the expected number $=100$.)

\begin{tabular}{|c|c|c|c|c|c|}
\hline \multicolumn{3}{|c|}{ Position of Cases } & $\begin{array}{l}\text { Pulmonary } \\
\text { Tuberculosis }\end{array}$ & $\begin{array}{l}\text { Pulmonary } \\
\text { with Meningeal and } \\
\text { Miliary Tuberculosis }\end{array}$ & All Types \\
\hline Same house & .. & .. & 345 & 348 & 304 \\
\hline Nexț door & .. & .. & 133 & 135 & 127 \\
\hline Next door bu & & .. & 110 & 109 & 109 \\
\hline Next door bu & & .. & 103 & 99 & 100 \\
\hline
\end{tabular}

suggests that " neighbourly contact" is one of the social customs responsible for spreading the disease. But before deciding that this was the only factor responsible for the present findings, it was necessary to compare the cases occurring in next-door pairs of houses with those found elsewhere, and a study was made of the age, social class, housing conditions, and family history of tuberculosis of the two groups of cases. The case histories were also scrutinized to discover how many of the patients living next door to other cases were related to one another (Table VIII, overleaf).*

According to this analysis the only significant differences are those in respect of social class I and good houses. Since day-to-day contact between neighbouring

* Since it is difficult to trace all female relationships, owing to the change of surname on marriage, a special survey of all patients still on the register was also made to discover whether two or more patients living next door to one another were related. This drew a complete blank. 
TABLE VIII

Pulmonary Tubfrculosis Notifications. Northampton 1921-1948

Comparison of Age, Social Class, Housing Conditions, and Family History* of Cases in Nextdoor Pairs of Houses and Other Houses

\begin{tabular}{|c|c|c|c|c|}
\hline Relationship of Houses & .. & . & Next-door Houses & Other Houses \\
\hline Age Group (years) & & $\begin{array}{r}0-14 \\
15-24 \\
25-44 \\
5+4\end{array}$ & $\begin{array}{r}2 \cdot 0 \\
31 \cdot 1 \\
41 \cdot 7 \\
25 \cdot 2\end{array}$ & $\begin{array}{r}2 \cdot 9 \\
30 \cdot 5 \\
43 \cdot 0 \\
23 \cdot 5\end{array}$ \\
\hline Social Class (males only) & & $\begin{array}{l}\text { I and II } \\
\text { III } \\
\text { IV and V } \\
\text { Unclassified }\end{array}$ & $\begin{array}{r}4 \cdot 6 \\
79 \cdot 6 \\
14 \cdot 4 \\
1 \cdot 4\end{array}$ & $\begin{array}{r}9 \cdot 2 \\
72 \cdot 3 \\
16 \cdot 0 \\
2 \cdot 5\end{array}$ \\
\hline Housing Conditions & & $\begin{array}{l}\text { Good } \\
\text { Fair } \\
\text { Poor }\end{array}$ & $\begin{array}{l}14 \cdot 3 \\
68 \cdot 1 \\
17 \cdot 5\end{array}$ & $\begin{array}{l}23 \cdot 0 \\
62 \cdot 9 \\
14 \cdot 0\end{array}$ \\
\hline \multicolumn{3}{|c|}{ Family History of Tuberculosis* } & $28 \cdot 0$ & $27 \cdot 5$ \\
\hline \multicolumn{3}{|c|}{$\begin{array}{l}\text { No. of Tuberculosis Subjects (not living in the } \\
\text { same house) known to be related to one } \\
\text { another } \\
\text {.. }\end{array}$} & 2 & 9 \\
\hline
\end{tabular}

* Restricted to grand-parents, parents, siblings, and offspring.

households is undoubtedly least in the least congested and wealthiest sections of the community, any transmission of infection should also be least in the best residential districts and in the highest income groups. Only two of the patients in the nextdoor pairs of affected houses were found to be related to one another, compared with nine in the remainder. These two figures are proportional to the total number of houses in the two groups (see Table IV).

\section{Sociological SURVeY}

\section{Sociological Features of Northampton COUNTY Borough}

(a) Population.-Between 1921 and 1948 there was an increase in the total number of inhabitants and a decrease in the proportion of children and adolescents living in Northampton. These and other population changes are similar to those which were occurring elsewhere in England and Wales.

(b) Trades and Occupations.- Shoemaking has long been the staple industry of Northampton; in 1921, and again in 1931, approximately 33 per cent. of the working population were employed in the boot and shoe industry and 5 per cent. in the leather-dressing trade. Engineering works, clothing factories, and breweries absorbed about 10 per cent. of all wage-earners up to 1939; there are no miners, quarrymen, or potters, and a negligible number of textile workers; the proportion of clerical workers, tradesmen, storekeepers, builders, and transport workers 
(approximately 30 per cent. of all wage-earners) is similar to that in other manufacturing towns.

(c) Economic Status.-According to the periodic surveys of the hours of work and earnings of manual workers made since 1924 (Ministry of Labour Gazette, 1924-1946), male shoemakers over the age of 20 tend to earn less than skilled artisans in other trades. This has had a direct bearing on the earnings of men belonging to social class III (skilled artisans) in Northampton and has reduced these below par, but there have been no major strikes in the boot and shoe industry since 1921 and very little unemployment. Other workers in the industry (women and juveniles) have always been relatively well paid, and even before 1939 a greater proportion of women were wage-earners in Northampton than elsewhere. Thus, the average income of all persons living in Northampton was slightly above par during the inter-war years. Since then there have been no air raids, virtually no unemployment, and an increase in the number of female wage-earners. It is likely, therefore, that throughout the period of study the economic position of Northampton has been relatively good.

(d) Vital Statistics.-For many years the vital statistics of Northampton County Borough have shown a favourable trend, and the infant, maternity, tuberculosis, and general death rates have declined pari passu with those of England and Wales as a whole. The improvement in the infant mortality rate is less than that recorded for England and Wales, but this is because from 1921 to 1925 there were only 59 deaths for every 1,000 live births in Northampton, whereas the corresponding rate for England and Wales was 76 . By 1948 both rates had declined to 36 .

To compare Northampton directly with other county boroughs the following statistics were examined:

(i) Social class distribution of males over the age of 14 (Registrar-General's Statistical Review, 1934. P. 144, Table XCVII).

(ii) Standardized mortality rates (males), 1931-1934 (calculated from figures published in the Registrar-General's Statistical Reviews).

(a) all causes;

(b) pulmonary tuberculosis.

(iii) Statutory overcrowding (i.e. households with more than two persons per room). (1931 Census).

(iv) Poor relief (i.e. persons in receipt of poor relief per 1,000 of the population, 1931-1933). (Hart and Wright, 1939).

In Table IX (overleaf) an unweighted average for each of these indices is shown for the county boroughs of England and Wales (arranged in five size groups) and for Northampton. In 1931 the following points were to be noted with regard to Northampton:

(i) the proportion of skilled manual workers (social class III) was above average;

(ii) the standardized mortality ratios for all causes of death and for pulmonary tuberculosis for males over 14 years of age were below average;

(iii) statutory overcrowding was conspicuously low; 
(iv) poor law relief was high compared with other towns of the same size, but did not exceed the average for all county boroughs.

On the whole, therefore, these statistics show that Northampton is favourably placed when compared with other county boroughs.

TABLE IX

English County Boroughs (1931 Census) Compared with Northampton

\begin{tabular}{|c|c|c|c|c|c|c|c|c|c|c|c|c|}
\hline \multicolumn{2}{|c|}{$\begin{array}{c}\text { English County } \\
\text { Boroughs }\end{array}$} & \multirow{3}{*}{$\begin{array}{c}\text { Average } \\
\text { popula- } \\
\text { tion }\end{array}$} & \multicolumn{5}{|c|}{ Males } & \multicolumn{4}{|c|}{ Housing Data } & \multirow{3}{*}{$\begin{array}{c}\mathbf{P} \\
\mathbf{o} \\
\mathbf{o} \\
\mathbf{r} \\
\mathbf{R} \\
\mathrm{e} \\
\mathbf{l} \\
\mathbf{i} \\
\mathrm{e} \\
\mathbf{f} \dagger\end{array}$} \\
\hline & & & \multicolumn{3}{|c|}{ Social class } & \multicolumn{2}{|c|}{$\begin{array}{c}\text { Standardized } \\
\text { mortality } \\
\text { ratio }\end{array}$} & \multirow{2}{*}{$\begin{array}{c}\text { Per- } \\
\text { sons } \\
\text { per } \\
\text { room }\end{array}$} & \multirow{2}{*}{$\begin{array}{c}\text { Per- } \\
\text { sons } \\
\text { per } \\
\text { acre }\end{array}$} & \multirow{2}{*}{$\begin{array}{l}\text { Per- } \\
\text { sons } \\
\text { per } \\
\text { dwel- } \\
\text { ling }\end{array}$} & \multirow{2}{*}{$\begin{array}{c}\text { Houses } \\
\text { over- } \\
\text { crowd- } \\
\text { ed* } \\
\%\end{array}$} & \\
\hline $\begin{array}{c}\text { (by popula- } \\
\text { tion) }\end{array}$ & No. & & $\begin{array}{c}\text { I } \\
\text { II }\end{array}$ & III & $\begin{array}{l}\text { IV } \\
\text { and } \\
\mathbf{V}\end{array}$ & $\begin{array}{l}\text { All } \\
\text { causes }\end{array}$ & $\begin{array}{c}\text { Pul- } \\
\text { mon- } \\
\text { ary } \\
\text { tuber- } \\
\text { culosis }\end{array}$ & & & & & \\
\hline $\begin{array}{r}\text { Under } 65,000 \\
, \quad 90,000 \\
, \quad 120,000 \\
2,200,000 \\
\text { Over } 200,000\end{array}$ & $\begin{array}{l}15 \\
17 \\
16 \\
15 \\
16\end{array}$ & $\begin{array}{r}54,000 \\
76,054 \\
104,815 \\
152,747 \\
421,733\end{array}$ & $\begin{array}{l}14 \\
12 \\
15 \\
12 \\
13\end{array}$ & $\begin{array}{l}50 \\
51 \\
51 \\
53 \\
51\end{array}$ & $\begin{array}{l}36 \\
37 \\
34 \\
35 \\
36\end{array}$ & $\begin{array}{l}107 \\
109 \\
113 \\
112 \\
115\end{array}$ & $\begin{array}{l}103 \\
107 \\
109 \\
119 \\
135\end{array}$ & $\begin{array}{l}0.83 \\
0.85 \\
0.86 \\
0.88 \\
0.89\end{array}$ & $\begin{array}{l}13 \\
17 \\
19 \\
23 \\
27\end{array}$ & $\begin{array}{l}4 \cdot 0 \\
4 \cdot 2 \\
4 \cdot 0 \\
4 \cdot 3 \\
4 \cdot 2\end{array}$ & $\begin{array}{l}7 \cdot 6 \\
7 \cdot 2 \\
8 \cdot 2 \\
7 \cdot 9 \\
8 \cdot 6\end{array}$ & $\begin{array}{l}21 \\
34 \\
28 \\
33 \\
45\end{array}$ \\
\hline Total & 79 & 162,264 & 13 & 51 & 36 & 111 & 115 & 0.86 & 20 & $4 \cdot 1$ & $7 \cdot 9$ & 33 \\
\hline NORTHAMPTON & & $92,314_{+}^{+}$ & 14 & 61 & 25 & 93 & 90 & $0 \cdot 70$ & $27_{+}^{+}$ & $3 \cdot 9$ & $2 \cdot 0$ & 33 \\
\hline
\end{tabular}

* i.e. with more than two persons per room.

+ Persons in receipt of poor relief per 1,000 of the population (1931-1933).

$\ddagger$ In March 1932 the boundaries of Northampton County Borough were extended, increasing the acreage from 3,469 to 6,201 and the population from 92,341 to 96,546 .

InTERnal Structure of Northampton County Borough.-To identify the size, nature, and position of the buildings and open spaces in a town, a street directory and an ordnance survey map are required. The cases of tuberculosis considered in this paper have therefore been restricted to those from houses standing in 1936-the only year for which a complete street directory for Northampton was available. There were then 26,769 occupied dwelling-houses and 96,300 inhabitants, and the borough boundary enclosed 6,201 acres. The town was divided into twelve electoral wards, seven with county borders (peripheral zone) and five surrounded by other wards (central zone). The houses in the central zone were more congested than those in the peripheral zone, but according to the records of the tuberculosis dispensary (which apply only to patients) there appeared to be a fairly even distribution of good, fair, and poor houses in most districts.

In classifying the houses in the borough, two or three rows of houses, described by the health visitor as fair, were identified in each ward. The health visitor and the chest physician to the borough (both of whom have worked in the tuberculosis 
TABLE $\mathrm{X}$

Northampton. Sociological Data

\begin{tabular}{|c|c|c|c|c|c|c|c|c|c|}
\hline \multirow{2}{*}{ Zone } & \multirow{2}{*}{ Ward } & \multirow{2}{*}{$\begin{array}{c}\text { Esti- } \\
\text { mated } \\
\text { Popula- } \\
\text { tion }\end{array}$} & \multicolumn{3}{|c|}{ Houses } & \multirow{2}{*}{$\begin{array}{c}\text { Persons } \\
\text { per } \\
\text { House }\end{array}$} & \multirow{2}{*}{$\begin{array}{c}\text { Total } \\
\text { Acreage } \\
\text { per } \\
\text { House }\end{array}$} & \multirow{2}{*}{$\begin{array}{c}\text { Restric- } \\
\text { ted } \\
\text { Acreage } \\
\text { per } \\
\text { House }\end{array}$} & \multirow{2}{*}{$\begin{array}{c}\text { Tuber- } \\
\text { culosis } \\
\text { notifica- } \\
\text { tions } \\
1921- \\
1948 \\
\text { per } 1,000 \\
\text { houses }\end{array}$} \\
\hline & & & Good & Fair & Poor & & & & \\
\hline \multirow[t]{2}{*}{ Peripheral } & $\begin{array}{l}1 \\
2 \\
3 \\
4 \\
5 \\
6 \\
7\end{array}$ & $\begin{array}{l}6,967 \\
4,197 \\
6,033 \\
8,405 \\
7,271 \\
7,995 \\
6,296\end{array}$ & $\begin{array}{r}2,924 \\
1,061 \\
810 \\
545 \\
289 \\
169 \\
144\end{array}$ & $\begin{array}{r}147 \\
735 \\
1,194 \\
1,669 \\
1,584 \\
1,552 \\
466\end{array}$ & $\begin{array}{r}- \\
- \\
86 \\
137 \\
152 \\
433\end{array}$ & $\begin{array}{l}2 \cdot 3 \\
2 \cdot 3 \\
3 \cdot 0 \\
3 \cdot 7 \\
3 \cdot 6 \\
4 \cdot 3 \\
6 \cdot 0\end{array}$ & $\begin{array}{l}3 \cdot 5 \\
2 \cdot 8 \\
3 \cdot 0 \\
3 \cdot 6 \\
3 \cdot 4 \\
1 \cdot 9 \\
1 \cdot 5\end{array}$ & $\begin{array}{r}9 \cdot 8 \\
7 \cdot 3 \\
10 \cdot 8 \\
13 \cdot 7 \\
19 \cdot 1 \\
17 \cdot 0 \\
17 \cdot 1\end{array}$ & $\begin{array}{r}5 \cdot 6 \\
5 \cdot 3 \\
8 \cdot 1 \\
9 \cdot 7 \\
7 \cdot 7 \\
10 \cdot 6 \\
10 \cdot 7\end{array}$ \\
\hline & Total & 47,164 & 5,942 & 7,347 & 808 & $3 \cdot 3$ & $2 \cdot 8$ & $11 \cdot 9$ & $8 \cdot 0$ \\
\hline \multirow[t]{2}{*}{ Central } & $\begin{array}{r}8 \\
9 \\
10 \\
11 \\
12\end{array}$ & $\begin{array}{r}8,692 \\
7,566 \\
10,800 \\
11,498 \\
10,832\end{array}$ & $\begin{array}{c}962 \\
727 \\
712 \\
57 \\
-\end{array}$ & $\begin{array}{r}1,284 \\
1,532 \\
2,139 \\
2,339 \\
831\end{array}$ & $\begin{array}{r}188 \\
5 \\
143 \\
520 \\
1,233\end{array}$ & $\begin{array}{l}3 \cdot 6 \\
3 \cdot 3 \\
3 \cdot 6 \\
3 \cdot 9 \\
5 \cdot 2\end{array}$ & $\begin{array}{r}5 \cdot 3 \\
16 \cdot 3 \\
16 \cdot 6 \\
19 \cdot 4 \\
11 \cdot 5\end{array}$ & $\begin{array}{l}11 \cdot 5 \\
25 \cdot 2 \\
19 \cdot 7 \\
24 \cdot 6 \\
32 \cdot 2\end{array}$ & $\begin{array}{r}7 \cdot 6 \\
8 \cdot 7 \\
8 \cdot 8 \\
10 \cdot 9 \\
12 \cdot 3\end{array}$ \\
\hline & Total & 49,388 & 2,458 & 8,125 & 2,089 & $3 \cdot 9$ & $11 \cdot 5$ & $19 \cdot 6$ & $9 \cdot 6$ \\
\hline All Regions & & 96,552 & 8,400 & 15,472 & 2,897 & $3 \cdot 6$ & $4 \cdot 3$ & $14 \cdot 6$ & $8 \cdot 7$ \\
\hline
\end{tabular}

dispensary for over 20 years) were then asked to mark the remaining houses as follows:

(i) those which corresponded to the standard houses ( fair);

(ii) those with better amenities (good);

(iii) those with worse amenities (poor).

In this way 36 more or less homogeneous groups were defined, corresponding to the three types of house in each ward.

When all the houses had been graded it was found that there were three wards in the peripheral zone with no poor houses and one in the central zone with no good houses. In nine wards (five peripheral and four central) there was a majority of fair houses, and in two peripheral wards a majority of good houses. Only one central ward had a majority of poor houses (Table X).

Since the built-up area of the town did not extend to the borough boundary,* the housing density, as judged by houses per acre, appeared to be very much greater in the peripheral than in the central zone.

When, however, the open country within the boundary but outside the built-up area, and all non-residential buildings and inaccessible open sites (e.g. railway sidings) were excluded, the difference between the peripheral and central wards was

* This was extended in 1932 and the acreage increased from 3,469 to 6,201 . As a result of this extension the 1931 population of 92,341 was increased to 96,546 . 
found to be much less. With this alternative index, a fairly close correlation was found between (i) density of houses and order of merit in terms of good, fair, and poor, and (ii) density of houses and tuberculosis notification rate per ward (Table $\mathrm{X})$.

The general amenities of Northampton compare favourably with those of other manufacturing towns of the same size, and the tuberculosis findings are unlikely to have been biased by exceptional social conditions. The absence of large pockets of extreme wealth and extreme poverty, and the fact that open country and large parks are easily accessible from all parts of the town, probably explains why the introduction of regional (i.e. ward) subdivisions into the mathematical calculations produced very little alteration in the " expected number of pairs of next-door houses affected with tuberculosis". On the other hand it is impossible to regard the town as a homogeneous unit. The division of the houses into three classes is, in the context, an attempt to classify the social and economic status of houses in the same way as the Registrar-General has classified the social and economic status of persons; but, although this served the main purpose of the present investigation, there is an obvious need for more objective standards.

\section{Discussion}

Deeny (1947) attempted to decipher the pattern of tuberculosis in a manufacturing town of 15,000 inhabitants by studying the arrangement of affected houses over a period of 25 years. He concluded that " the main factor which enables the disease to spread and cause deaths is the residence of adolescents in near proximity to, or neighbourly contact with, a case which dies ".

The present investigation has much in common with its predecessor, but covers a slightly longer period and makes no distinction between fatal and non-fatal cases of tuberculosis. It relates to a population largely composed of workers in one industry, but since the town is much larger (approximately 100,000 inhabitants) the investigation has had to allow for variations in social amenities and types of house in different parts of the town. Instead of relying on visual impressions to decide whether the affected houses show a tendency to aggregation or clumping, a more objective assessment of the findings has been attempted.

From 1921 to 1948 the social amenities and economic status of the inhabitants of Northampton were relatively good, but the town itself experienced many changes. Old houses were demolished, new houses built, and new industries established; no building was damaged during the second world war, but many of the inhabitants were called up for national service, large numbers of evacuees were temporarily accommodated, and many residents changed their addresses.

All these changes tend to blur the pattern of a disease which moves slowly and leaves behind only an imperfect record of its course, and to reduce to a minimum the "positive findings" of an investigation based on a comparison of observed and expected relationships, ignoring the movement of persons from house to 
house, and restricting the definition of a neighbour to " a person living in an adjacent house on the same side of the street ". Nevertheless, the faint outline of a pattern has been discerned which is apparently due not to social, economic, or occupational factors, nor to an exceptionally large number of related persons in next-door houses, but to the spread of the disease between neighbours. Exactly what contribution this mode of spread, which appears to be due to infective and not to genetic factors, has made to the total amount of overt tuberculosis it is impossible to say; but it is certainly no less and possibly much greater than that which has been shown to exist.

The work of Stocks (1935) only came to our notice after this paper was in proof. He studied the frequency of deaths from cancer in the same house and in neighbouring houses by methods in essence identical with those developed independently for this study of tuberculosis. He found that:

Cancer deaths tend to occur in pairs more frequently in the same or adjacent houses than would be expected if the population at risk was distributed uniformly in the houses and the deaths took place at random in the population. . . . An exactly similar study of the distribution of persons aged 55 to 75 . . . shows . . . precisely the same result. . . . To postulate any theory of infection to "explain" the curious distribution of cancer deaths in houses is therefore redundant, since it can be sufficiently explained by the tendency to segregation in the same or adjacent houses of people of those ages at which cancer death is of most frequent occurrence.

It may well be asked whether these tuberculosis figures can be similarly dismissed. It is not possible to test the point explicitly in the way that Stocks did, owing to the destruction by fire in 1942 of the 1931 Census records. But tuberculosis is not nearly so restricted in its age-incidence as is cancer. Consequently its pattern will be less affected by any uneven distribution of population by age in the same or nearby houses. Moreover, Stocks found " no conclusive evidence that when cancer deaths occur in pairs in the same or neighbouring houses there is any tendency for them to be separated by a short rather than a long interval ". The undue preponderance of pairs of cases of tuberculosis occurring within a short period of years in the same and next-door houses is a distinctive feature of the present data, and supports our contention that tuberculosis may spread from one house to that next door.

\section{SUMMARY}

The present investigation was undertaken to discover whether persons living next door or near to a tuberculous subject run more risk of contracting the disease.

The investigation was based on statistics for Northampton, which is comparable in standards of living and population structure to other towns of the same size in England and Wales.

Over a period of 28 years (1921 to 1948) notifications of tuberculosis were reported from 2,871 houses standing in the borough in 1936. Approximately 
20 per cent. of the affected houses were grouped in pairs or in runs of three or more.

The number of next-door pairs of houses which would have been affected had the cases been distributed at random was calculated by means of formulae derived from the mathematical theory of the random distribution of points in one dimension. Allowance was made for differences between good, fair, and poor housing, but only the interrelationships of houses on the same side of a street were taken into consideration.

The number of affected houses standing next door to one another was found to be significantly greater than the number to be expected had the cases been randomly distributed.

When the time relationships of the cases were investigated it was found that for any period up to 12 years the number of pairs of cases reported from the same house and from next-door houses was significantly in excess of the number to be expected from pure chance.

There is no evidence that these findings are due to there being an exceptionally large number of related persons living next door to one another.

Our sincere thanks are due to Dr. N. B. Laughton and the staff of the Northampton Health Clinic, whose help and careful record-keeping have made this survey possible.

Deeny, J. (1947). J. med. Ass. Eire, 21, 82.

\section{REFERENCES}

Hart, P. D'Arcy, and Wright, G. P. (1939). " " Tuberculosis and Social Conditions in England." National Association for the Prevention of Tuberculosis, London.

Stocks, P. (1935). J. Hyg., Camb., 35, 46.

Census of England and Wales, 1921 and 1931.

Ministry of Labour Gazettes, 1924-1946.

Registrar-General's Statistical Reviews for England and Wales. 


\section{STATISTICAL APPENDIX \\ BY}

\section{IAN SUTHERLAND}

The problem of assessing whether the pattern of tuberculosis in affected houses is random or not is of some statistical interest. In the first place, considerable care has to be taken to cast the actual data into a form which can validly be compared with a theoretical model. Secondly, an extension of existing mathematical theory is necessary for this model. The interest lies in the inter-action between the theoretical and practical sides of the problem. It will be studied in two stages:

(a) if there is spread of the disease from one house to another there will be an undue clustering of affected houses in space;

(b) there will also be an undue tendency for neighbouring cases of the disease to cluster in time.

\section{Spatial Pattern of Affected Houses}

Each street was first divided into "sections" (rows of houses on the same side of a street uninterrupted by non-domestic buildings, or by side streets). These sections varied in size from one to eighty houses. The average number of houses per section was $13 \cdot 9$. The prime purpose of this division was to reduce a mathematically awkward two-dimensional to a tractable one-dimensional problem, but it also groups the houses in conformity with the accepted notion of a row of neighbouring houses.

It was next necessary to assess the clustering of affected houses. One method was to determine how many " runs" of two, three, four, or more affected houses occurred. This had the disadvantage that there were few runs of more than two. In all the 2,871 affected houses there were only 29 runs of three affected houses, three of four, and one of five. Also this method took no cognizance of any clustering which did not result in actual runs. It was therefore decided to assess clustering by enumerating " interval-pairs" (pairs of affected houses in the same streetsection standing a stated number of doors away from each other). These were enumerated for intervals of $1,2,3,4,5$, and 6 houses. The totals had then to be compared with the numbers to be expected if the distribution of affected houses were random.

Mathematical Theory.-The probability distributions of points on a line were studied extensively by Krishna Iyer (1948). He did not, however, consider the concept of an interval-pair except in the case of an interval of one (a " black-black join "). The theory can be extended to include the general interval-pair by applying the formulae given by Moran (1948). If the probability of a house being affected is $p$ in a section of 
$n$ houses, then the first two moments of the distribution of the number of pairs of affected houses which are $r$ doors away from each other are given by the formulae:

$$
\begin{aligned}
& \mu_{1}=(n-r) p^{2} \quad \text { if } r=1 \ldots \ldots n-1 \\
& \mu_{2}=(n-r) p^{2}+2(n-2 r) p^{3}-(3 n-5 r) p^{4} \text { if } r=1 \quad \ldots \ldots\left[\begin{array}{c}
n-1 \\
2
\end{array}\right] \\
& \mu_{2}=(n-r) p^{2}-(n-r) p^{4} \quad \text { if } r==\left[\begin{array}{c}
n+1 \\
2
\end{array}\right] \ldots n-1
\end{aligned}
$$

The third and fourth moments have also been derived, but are considerably more complicated, both in their form and in the boundary conditions.

If there is a group of $s$ sections for which $p$ is constant, the average length of the section being $\bar{n}$, the first two moments of the total number of pairs of affected houses and doors apart are seen to be:

$$
\begin{array}{llll}
\mu_{1}^{\prime}=s(\bar{n}-r) p^{2} & \text { if every } n \text { satisfies } r=1 & \ldots & n-1 \\
\mu_{2}=s(\bar{n}-r) p^{2}+2 s(\bar{n}-2 r) p^{3}-s(3 \bar{n}-5 r) p^{4} & \text { if every } n \text { satisfies } r=1 & \ldots & \ldots \\
\mu_{2}=s(\bar{n}-r) p^{2}+s(\bar{n}-r) p^{4} & \text { if every } n \text { satisfies } r=\left[\begin{array}{c}
n-1 \\
2 \\
-2
\end{array}\right]
\end{array}
$$

These boundary conditions for $\mu_{2}$ are very inconvenient, particularly when $r$ is large. This is the principal reason why pairs were not enumerated for $r>6$. The following approximate procedure has been adopted in the ensuing analysis of groups of sections. The population value of $p$ has been estimated by the ratio of affected houses to all houses in the group of sections analysed. The expected totals of affected pairs one to six doors away from each other have been calculated from formula (i) for all sections for which $r \leqslant n-1$. The variances have been calculated from formula (ii), with the parameters appropriate to all sections for which $r \leqslant n-1$. These variances will be overestimated, but since sections for which $\left[\frac{n-1}{2}\right]<r \leqslant n-1$ will be in a minority except for large $r$, the approximation will affect the estimate only slightly; in any case the tests of significance will err on the side of caution. The tests were made on the assumption that the number of interval-pairs is normally distributed.

One further point remains. Formulae (i) and (ii) are valid only if $p$ is constant throughout the group of $s$ sections. It is thus necessary to divide the street sections into suitable groups before analysing the data, and then to sum the results. Originally the data were arranged in 32 separate groups, representing the good, fair, and poor houses in each of the twelve electoral wards (there were no good houses in one ward and no poor houses in three). It was clearly desirable, however, because of the computations involved, to handle fewer groups, provided that no serious discrepancy arose by so doing. As a trial, therefore, the expected numbers of next-door pairs of affected houses were calculated for each of the 32 groups separately, and also for various amalgamations of them. The findings are presented in Table XI. The arrows in this table show that the effect of progressive subdivision of relatively large groups of data into smaller and more nearly homogeneous groups is to increase the expected numbers of next-door pairs of affected houses. It will be seen, however, that the introduction of regional subdivisions (vertical arrows) produces relatively little increase in the expected numbers compared with the subdivision into good, fair, and poor housing (diagonal arrows). On these findings, it was decided that it would be sufficiently accurate to analyse the data in three groups, classified according to standard of housing. The resulting "expected" numbers are, however, rather lower than if it had been possible to account for all local variations in the incidence of tuberculosis. 
TABLE XI

TUberculosis Notifications. NORThampton 1921-1948

Expected Numbers of Next-Door Pairs of Affected Houses

\begin{tabular}{|c|c|c|c|c|c|c|c|c|}
\hline \multicolumn{3}{|c|}{$\begin{array}{l}\text { Groups of Houses Regarded as } \\
\text { Homogeneous* }\end{array}$} & \multicolumn{3}{|c|}{$\begin{array}{l}\text { Number of } \\
\text { Homogeneous Groups } \\
\text { in Northampton }\end{array}$} & \multicolumn{3}{|c|}{$\begin{array}{l}\text { Expected Numbers of } \\
\text { Next-door Pairs }\end{array}$} \\
\hline \multicolumn{3}{|l|}{ Whole town } & \multicolumn{3}{|c|}{1} & \multicolumn{3}{|l|}{$189 \cdot 2$} \\
\hline \multicolumn{3}{|c|}{ Good, fair, and poor houses } & \multicolumn{3}{|c|}{3} & \multicolumn{3}{|c|}{$198 \cdot 8$} \\
\hline \multicolumn{3}{|c|}{ Central and peripheral districts .. } & \multicolumn{3}{|c|}{2} & \multicolumn{3}{|c|}{ 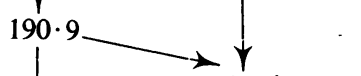 } \\
\hline \multicolumn{2}{|c|}{ Housing within districts $\ldots \quad \ldots$} & & \multicolumn{3}{|c|}{6} & \multicolumn{3}{|c|}{$\quad 199 \cdot 1$} \\
\hline \multicolumn{3}{|c|}{$\begin{array}{llll}\text { Electoral wards } & \ldots & \ldots & \ldots\end{array}$} & \multicolumn{3}{|c|}{12} & \multicolumn{3}{|c|}{$198 \cdot 4$} \\
\hline \multicolumn{3}{|c|}{ Housing within wards $\quad}$. & \multicolumn{3}{|c|}{32} & \multicolumn{3}{|c|}{$204 \cdot 3$} \\
\hline \multicolumn{3}{|c|}{ Actual number of next-door pairs } & & & $=$ & \multicolumn{3}{|l|}{231} \\
\hline \multicolumn{9}{|c|}{$\begin{array}{l}\text { * In this context a homogeneous group is defined as one in which it is assumed that all the houses } \\
\text { are equally liable to be affected. }\end{array}$} \\
\hline \multicolumn{9}{|c|}{$\begin{array}{l}\text { FINDINGS. - The data were analysed in three stages (see Table XII): } \\
\text { (a) houses containing only cases of pulmonary tuberculosis; } \\
\text { (b) houses containing cases of pulmonary, miliary or meningeal tuberculosis; } \\
\text { (c) houses containing any type of tuberculosis. }\end{array}$} \\
\hline \multirow{2}{*}{\multicolumn{9}{|c|}{$\begin{array}{c}\text { TUBERCULOSIS NOTIFICATIONS. NORTHAMPTON 1921-1948 } \\
\text { SPATIAL RELATIONSHIPS } \\
\text { Comparison of Actual and Expected Numbers of Interval-Pairs of Affected Houses } \\
\text { (Based on a separate analysis of good, fair, and poor houses) }\end{array}$}} \\
\hline & & & & & & & & \\
\hline \multicolumn{3}{|c|}{ Disease Category } & \multicolumn{6}{|c|}{ Relationship of Affected Houses } \\
\hline \multirow{2}{*}{\multicolumn{3}{|c|}{ Houses affected with }} & \multirow{2}{*}{$\begin{array}{l}\text { Next } \\
\text { door }\end{array}$} & \multicolumn{5}{|c|}{ Next door but } \\
\hline & & & & 1 & 2 & 3 & 4 & 5 \\
\hline $\begin{array}{l}\text { Pulmonary } \\
\text { Tuberculosis }\end{array}$ & $\begin{array}{l}\text { Actual } \\
\text { Expected ... } \\
\text { Difference } \\
\text { S.E. of Diff. } \\
\text { Diff./S.E. }\end{array}$ & 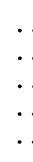 & $\begin{array}{r}231 \\
198 \cdot 8 \\
32 \cdot 2 \\
15 \cdot 1 \\
2 \cdot 1\end{array}$ & $\begin{array}{r}182 \\
182 \cdot 8 \\
-0 \cdot 8 \\
14 \cdot 4 \\
-0 \cdot 1\end{array}$ & $\begin{array}{r}191 \\
169 \cdot 4 \\
21 \cdot 6 \\
13 \cdot 8 \\
1 \cdot 6\end{array}$ & $\begin{array}{r}157 \\
155 \cdot 8 \\
1 \cdot 2 \\
13 \cdot 1 \\
0.9\end{array}$ & $\begin{array}{r}144 \\
143 \cdot 6 \\
0 \cdot 4 \\
12 \cdot 5 \\
0 \cdot 0\end{array}$ & $\begin{array}{r}117 \\
131 \cdot 0 \\
-14 \cdot 0 \\
11 \cdot 9 \\
-\quad 1 \cdot 2\end{array}$ \\
\hline $\begin{array}{l}\text { Pulmonary, } \\
\text { Miliary, or } \\
\text { Meningeal } \\
\text { Tuberculosis }\end{array}$ & $\begin{array}{l}\text { Actual } \\
\text { Expected ... } \\
\text { Difference } \\
\text { S.E. of Diff. } \\
\text { Diff./S.E. }\end{array}$ & $\begin{array}{l}\cdots \\
\cdots \\
\cdots\end{array}$ & $\begin{array}{r}264 \\
220 \cdot 5 \\
43 \cdot 5 \\
16 \cdot 0 \\
2 \cdot 7\end{array}$ & $\begin{array}{r}204 \\
202 \cdot 9 \\
1 \cdot 1 \\
15 \cdot 2 \\
0 \cdot 1\end{array}$ & $\begin{array}{r}209 \\
187 \cdot 8 \\
21 \cdot 2 \\
14 \cdot 5 \\
1 \cdot 5\end{array}$ & $\begin{array}{r}174 \\
172 \cdot 6 \\
1 \cdot 4 \\
13 \cdot 9 \\
0 \cdot 1\end{array}$ & $\begin{array}{r}167 \\
158 \cdot 9 \\
8 \cdot 1 \\
13 \cdot 2 \\
0 \cdot 6\end{array}$ & $\begin{array}{r}132 \\
144 \cdot 8 \\
-12 \cdot 8 \\
12 \cdot 5 \\
-1 \cdot 0\end{array}$ \\
\hline $\begin{array}{l}\text { Any Type of } \\
\text { Tuberculosis }\end{array}$ & $\begin{array}{l}\text { Actual } \\
\text { Expected } . \\
\text { Difference } \\
\text { S.E. of Diff. } \\
\text { Diff./S.E. }\end{array}$ & . & $\begin{array}{r}353 \\
297 \cdot 4 \\
55 \cdot 6 \\
18 \cdot 7 \\
3 \cdot 0\end{array}$ & $\begin{array}{r}286 \\
274 \cdot 3 \\
11 \cdot 7 \\
17 \cdot 8 \\
0 \cdot 7\end{array}$ & $\begin{array}{r}279 \\
254 \cdot 2 \\
24 \cdot 8 \\
17 \cdot 0 \\
1 \cdot 5\end{array}$ & $\begin{array}{r}236 \\
234 \cdot 0 \\
2 \cdot 0 \\
16 \cdot 2 \\
0 \cdot 1\end{array}$ & $\begin{array}{r}219 \\
215 \cdot 7 \\
3 \cdot 3 \\
15 \cdot 5 \\
0 \cdot 2\end{array}$ & $\begin{array}{r}187 \\
197 \cdot 0 \\
-10 \cdot 0 \\
14 \cdot 7 \\
-0.7\end{array}$ \\
\hline
\end{tabular}


For houses affected with pulmonary tuberculosis, the number of next-door pairs was 231 , compared with the expected value of $198 \cdot 8$. The excess is just greater than twice its standard error, and may be adjudged significant. None of the differences between actual and expected numbers of other interval-pairs is significant. Similar conclusions apply to houses affected with pulmonary, miliary, or meningeal tuberculosis, and also to houses affected with any form of tuberculosis. The excesses over expectation of next-door pairs become progressively more significant as more forms of tuberculosis are included, but none of the findings for intervals of more than one even approaches a significant level.

- This analysis has taken no cognizance of the effects of movement of population, since only the house from which the disease was notified has been regarded as affected. If, however, a house containing a case of tuberculosis is liable to lead to a case in a neighbouring house, then the removal of the patient to another house removes one source of danger, but creates another elsewhere. The effect of this would probably be to increase the relative frequency of apparently scattered cases of tuberculosis, and so to obscure rather than exaggerate any danger there may be in living next door to a person suffering from tuberculosis.

This influence, and that of further subdivision of the data into smaller and more homogeneous groups (Table XI), are both imponderable. Since, however, they appear to have the opposite effect on the " expected " figures they will to some extent cancel one another out. In any case, the next-door pairs appear to be in a category distinct from pairs at greater intervals. It therefore seems justifiable to conclude that there is some evidence of tuberculosis having passed from one house to the next.

\section{Pattern of The Disease in Time}

It was a natural extension of the above analysis to proceed from the consideration of houses affected with tuberculosis to the actual cases of the disease, and to see whether those which had arisen in the same or nearby houses were more closely related in time than would be expected from chance alone.

The intervals between the years of notification of every pair of cases occurring in the same or near-by houses were enumerated. (If more than one case was notified from a house in one year, this was treated, for theoretical reasons, as a single notification.) Four separate enumerations were made of pairs of cases occurring in the same house, in houses next door, next door but one, and next door but two. These totals had then to be compared with the numbers to be expected if the distribution of time-intervals were random.

Mathematical TheORY.- Theoretically this reduces to a distribution problem of points on a rectangular lattice, the lattice being the experience of a "section" of $n$ houses over $m$ successive years. Since there were substantial fluctuations in the annual notifications of tuberculosis it is necessary to consider a lattice on which the probability that a point is affected varies along the time-dimension of the lattice, a configuration not previously studied. Let $p_{j}$ be the probability that tuberculosis is notified from a given house in a section of $n$ houses in the year $j(j=1 \ldots m)$. Then the first two moments of the 
distribution of pairs of notifications separated by an interval of $t$ years, and occurring $r$ doors away from each other, are given by the formulae:

$$
\begin{aligned}
& \mu_{1}^{\prime}=2(n-r) \sum_{j=1}^{m-t} p_{j} p_{j+t} \text { if } r=1 \ldots n-1 ; t=1 \ldots m-1 . \\
& \mu_{1}^{\prime}=\text { half this quantity if } r=1 \ldots n-1 ; t=0 \text {. } \\
& \text { or } r=0 ; \quad t=1 \ldots m-1 \text {. } \\
& \text { or } r=t=0 \text {. } \\
& \mu_{2}=2(n-r) \sum_{j=1}^{m-t} p_{j} p_{j+t}+2(n-2 r) \sum_{j=1}^{m-t} p_{j}^{2} p_{j+t}+2(n-2 r) \sum_{j=1}^{m-t} p_{j} p_{j+t}^{2} \\
& +4(2 n-3 r) \sum_{j=1}^{m-2 t} p_{j} p_{j+t} p_{j+2 t}-2(3 n-5 r) \sum_{j=1}^{m-t} p_{j}^{2} p_{j+t}^{2} \\
& -4(2 n-3 r) \sum_{j=1}^{m-2 t} p_{j} p_{j+t}^{2} p_{j+2 t} \\
& \text { if } r=1 \ldots\left[\frac{n-1}{2}\right] ; t=1 \ldots m-1 \text {. } \\
& \mu_{1}=\text { half this quantity if } r=1 \ldots\left[\begin{array}{c}
n-1 \\
2
\end{array}\right] ; t=0 \text {. } \\
& \mu_{2}=n \sum_{j=1}^{m} p_{j}^{2} \quad \text { if } r=t=0 \text {. } \\
& t=1 \ldots m-1 \text {. }
\end{aligned}
$$

If there is a group of $s$ sections, each with the same values of $p_{j}$, the average length of section being $\bar{n}$, the first two moments of the total number of pairs of notifications separated by $t$ years, and $r$ doors away from each other, are given by the formulae:

$$
\begin{aligned}
& \mu_{1}^{\prime}=2 s(\bar{n}-r) \sum_{j=1}^{m-t} p_{j} p_{j+t} \text { if every } n \text { satisfies } r=1 \ldots n-1 ; \text { and } t=1 \ldots m-1 \\
& \mu_{1}=\text { half this quantity if every } n \text { satisfies } r=1 \ldots n-1 \text {; and } t=0 \text {. } \\
& \text { or } r=0 ; \quad \text { and } t=1 \ldots m-1 \text {. } \\
& \text { or } r=t=0 \text {. } \\
& \mu_{2}=2 s(\bar{n}-r) \sum_{j=1}^{m-t} p_{j} p_{j+t}+2 s(\bar{n}-2 r) \sum_{j=1}^{m-t} p_{j}^{2} p_{j+t}+2 s(\bar{n}-2 r) \sum_{j=1}^{m-t} p_{j} p_{j+t}^{2} \\
& +4 s(2 \pi-3 r) \sum_{j=1}^{m-2 t} p_{j} p_{j+t} p_{j+2 t}-2 s(3 n-5 r) \sum_{j=1}^{m-t} p_{j}^{2} p_{j+t}^{2} \\
& \text {-. } 4 s(2 \bar{n}-3 r) \sum_{j=1}^{m-2 t} p_{j} p_{j+i}^{2} p_{j+2 t} \\
& \text { if every } n \text { satisfies } r=1 \ldots\left[\frac{n-1}{2}\right] \text {; and } t=1 \ldots m-1 \\
& \mu_{2}=\text { half this quantity if every } n \text { satisfies } r=1 \ldots\left[\frac{n-1}{2}\right] \text {; and } t=0 \text {. } \\
& \text { or } r=0 ; \quad \text { and } t=1 \ldots m-1 \text {. } \\
& \mu=s \bar{n} \sum_{j=1}^{m} p_{j}^{2} \quad \text { if } r=t=0
\end{aligned}
$$


In applying these formulae the following approximations and assumptions were made. The values of $p_{j}$ were assumed to be constant throughout all sections with good housing, and fair housing, and poor housing; the expectations and variances for the three groups were added after the calculations had been made. The values of $p_{j}$ were estimated by the ratio of all notifications during the year $j$ to the number of houses in the particular group of sections. Expectations and variances were calculated from formulae (iii) to (vii) with the parameters appropriate to all sections for which $r \leqslant n-1$. The variances will be, as before, slightly overestimated by formulae (v) and (vi), and so the tests of significance will err on the side of caution. These tests were made on the assumption that the numbers of pairs are normally distributed.

TABLE XIII

TUBERCULOSIS NOTIFICATIONS. NORTHAMPTON 1921-1948

RELATIONSHIPS IN TIME

Comparison of Actual and Expected Numbers of Pairs of Cases, according to the Time-Interval between the Notifications in the Same or Neighbouring Houses

(Based on a separate analysis of good, fair, and poor houses)

\begin{tabular}{|c|c|c|c|c|c|c|c|c|c|}
\hline \multirow{3}{*}{$\begin{array}{l}\text { Disease } \\
\text { Category }\end{array}$} & \multirow{3}{*}{$\begin{array}{c}\text { Time } \\
\text { Interval } \\
\text { (years) }\end{array}$} & \multicolumn{8}{|c|}{ Relationship of Affected Houses } \\
\hline & & Same & House & Nex & Door & Next $\mathrm{D}$ & $\begin{array}{l}\text { Ooor but } \\
\text { ne }\end{array}$ & ${ }_{\text {Next I }}$ & $\begin{array}{l}\text { Door but } \\
\text { [wo }\end{array}$ \\
\hline & & Actual & Expected & Actual & Expected & Actual & Expected & Actual & Expected \\
\hline \multirow[t]{2}{*}{$\begin{array}{l}\text { Pulmonary } \\
\text { Tuberculosis }\end{array}$} & $\begin{array}{c}0-3 \\
4-7 \\
8-11 \\
12-15 \\
16-19 \\
20-23 \\
24-27\end{array}$ & $\begin{array}{r}179 \\
99 \\
40 \\
34 \\
22 \\
6 \\
3\end{array}$ & $\begin{array}{c}37 \cdot 87 * \\
30 \cdot 06 * \\
24 \cdot 24 * \\
19 \cdot 62 * \\
15 \cdot 28 \\
10 \cdot 44 \\
4 \cdot 13\end{array}$ & $\begin{array}{r}84 \\
67 \\
63 \\
36 \\
27 \\
20 \\
7\end{array}$ & $\begin{array}{c}60 \cdot 49 * \\
55 \cdot 68 \\
44 \cdot 89 * \\
36 \cdot 35 \\
28 \cdot 32 \\
19 \cdot 33 \\
7 \cdot 64\end{array}$ & $\begin{array}{r}66 \\
58 \\
40 \\
25 \\
24 \\
19 \\
3\end{array}$ & $\begin{array}{r}55 \cdot 83 \\
51 \cdot 36 \\
41 \cdot 41 \\
33 \cdot 56 \\
26 \cdot 12 \\
17 \cdot 82 \\
7 \cdot 04\end{array}$ & $\begin{array}{r}55 \\
47 \\
39 \\
35 \\
26 \\
16 \\
8\end{array}$ & $\begin{array}{r}51 \cdot 45 \\
47 \cdot 34 \\
38 \cdot 18 \\
30 \cdot 93 \\
24 \cdot 07 \\
16 \cdot 44 \\
6 \cdot 47\end{array}$ \\
\hline & $\underset{\text { intervals }}{\text { All }}$ & 383 & $141 \cdot 64^{*}$ & 304 & $252 \cdot 70 *$ & 235 & $233 \cdot 14$ & 226 & $214 \cdot 88$ \\
\hline \multirow[t]{2}{*}{$\begin{array}{l}\text { Pulmonary, } \\
\text { Miliary, or } \\
\text { Meningeal } \\
\text { Tuberculosis }\end{array}$} & $\begin{array}{c}0-3 \\
4-7 \\
8-11 \\
12-15 \\
16-19 \\
20-23 \\
24-27\end{array}$ & $\begin{array}{r}210 \\
104 \\
47 \\
38 \\
26 \\
7 \\
4\end{array}$ & $\begin{array}{c}42 \cdot 83^{*} \\
33 \cdot 58 * \\
27 \cdot 24^{*} \\
22 \cdot 03 * \\
17 \cdot 12 * \\
11 \cdot 61 \\
4 \cdot 53\end{array}$ & $\begin{array}{l}97 \\
77 \\
71 \\
42 \\
31 \\
21 \\
10\end{array}$ & $\begin{array}{c}68 \cdot 46^{*} \\
62 \cdot 16 \\
50 \cdot 43^{*} \\
40 \cdot 84 \\
31 \cdot 71 \\
21 \cdot 48 \\
8 \cdot 38\end{array}$ & $\begin{array}{r}77 \\
62 \\
43 \\
31 \\
28 \\
22 \\
4\end{array}$ & $\begin{array}{r}63 \cdot 15 \\
57 \cdot 33 \\
46 \cdot 52 \\
37 \cdot 70 \\
29 \cdot 24 \\
19 \cdot 81 \\
7 \cdot 72\end{array}$ & $\begin{array}{r}60 \\
51 \\
42 \\
41 \\
28 \\
20 \\
8\end{array}$ & $\begin{array}{r}58 \cdot 18 \\
52 \cdot 80 \\
42 \cdot 86 \\
34 \cdot 75 \\
26 \cdot 94 \\
18 \cdot 28 \\
7 \cdot 12\end{array}$ \\
\hline & $\begin{array}{c}\text { All } \\
\text { intervals }\end{array}$ & 436 & $158 \cdot 94 *$ & 349 & $283 \cdot 46 *$ & 267 & $261 \cdot 47$ & 250 & $240 \cdot 93$ \\
\hline \multirow[t]{2}{*}{$\begin{array}{l}\text { Any Type of } \\
\text { Tuberculosis }\end{array}$} & $\begin{array}{c}0-3 \\
4-7 \\
8-11 \\
12-15 \\
16-19 \\
20-23 \\
24-27\end{array}$ & $\begin{array}{r}250 \\
130 \\
62 \\
48 \\
33 \\
14 \\
4\end{array}$ & $\begin{array}{c}59 \cdot 24^{*} \\
47 \cdot 97^{*} \\
38 \cdot 14^{*} \\
30 \cdot 61^{*} \\
23 \cdot 53 \\
15 \cdot 42 \\
5 \cdot 61\end{array}$ & $\begin{array}{r}132 \\
100 \\
92 \\
57 \\
49 \\
28 \\
16\end{array}$ & $\begin{array}{l}94 \cdot 75^{*} \\
88 \cdot 78 \\
70 \cdot 64^{*} \\
56 \cdot 68 \\
43 \cdot 60 \\
28 \cdot 57 \\
10 \cdot 30\end{array}$ & $\begin{array}{r}102 \\
88 \\
65 \\
46 \\
48 \\
30 \\
6\end{array}$ & $\begin{array}{r}87 \cdot 39 \\
81 \cdot 88 \\
65 \cdot 17 \\
52 \cdot 28 \\
40 \cdot 24 \\
26 \cdot 33 \\
9 \cdot 48\end{array}$ & $\begin{array}{l}85 \\
69 \\
61 \\
58 \\
33 \\
25 \\
11\end{array}$ & $\begin{array}{r}80 \cdot 51 \\
75 \cdot 43 \\
60 \cdot 04 \\
48 \cdot 18 \\
37 \cdot 09 \\
24 \cdot 27 \\
8 \cdot 74\end{array}$ \\
\hline & $\underset{\text { intervals }}{\text { All }}$ & 541 & $220 \cdot 52 *$ & 474 & $393 \cdot 32 *$ & 385 & $362 \cdot 77$ & 342 & $334 \cdot 26$ \\
\hline
\end{tabular}

* The difference between observed and expected numbers exceeds twice the standard error. Each standard error is slightly greater than the square root of the expected number, but in no instance by more than 3 per cent 
FindiNGS.-The data relating to time intervals were also analysed in three stages, first for cases of pulmonary tuberculosis, then for cases of pulmonary, miliary, or meningeal tuberculosis, and finally for any form of tuberculosis. For each of these groups of cases, the time-relations in the same house, in houses next door, next door but one, and next door but two, were studied, and the results are summarized in Table XIII (previous page).

The observed numbers of pairs of cases occurring in the same house substantially (and significantly) exceed the expected numbers for intervals up to 15 years; the figures are suggestive of an excess after an interval of 16-19 years, but for longer intervals the differences are unimportant. This is true for each of the three groups of cases. The finding confirms the known fact that tuberculosis may continue to spread between members of a household over a period of years.

The experience in next-door houses shows an excess over expectation for intervals of less than 12 years, which attains significance for each of the three disease groups. For intervals of 12 years and over there is no important difference between the observed and expected figures. This more detailed analysis confirms the slight tendency shown above for tuberculosis to pass from one house to that next door, and gives the further information that this method of transmission of the disease may take up to 12 years to manifest itself. Comparison of the observed and expected figures for houses two or three doors away from each other shows no significant differences for any interval of time.

In conclusion, therefore, there is evidence of a slight tendency for tuberculosis to pass from one house to that next door within a period of 12 years from the detection of the original case. The analysis also confirms the known fact that tuberculosis is liable to spread among members of a household. This effect may be observed for intervals up to 15 years. 